\title{
A STUDY ON CONGENITAL ANOMALIES OF CENTRAL NERVOUS SYSTEM
}

\author{
Sailaja. K*.
}

*Assistant Professor, Dept. Of Anatomy, Govt. Medical College, Calicut, India.

\section{ABSTRACT}

Background: CNS malformations are one of the most common among congenital malformations rating to $5-10 \%$ of total malformations. Therefore, the present study was performed to evaluate the congenital anomalies in the central nervous system.

Materials and Methods: Patients of paediatric age group (1-12) years suspect to have congenital anomalies of CNS were followed up. Data on imaging studies were collected and tabulated. Antenatally diagnosed cases of CNS anomalies were followed up. Examination for associated anomalies of head, eyes, ears, nose, face, palate, thorax, abdomen and genitalia, back, upper limb, lower limb and additional points if any was also recorded. The Ultrasound, CT scan, MRI scan and other relevant investigations if any was also performed.

Results: In the present study 30 cases of congenital malformations were identified. Out of 30 cases 14 of them were neural tube defects, 13 microcephaly, 2 Dandy Walker alformations and one holoprosencephaly. Out of 14 neural tube defects 9 of them are lumbar myelomeningocoele, two encephalocoeles in the occipital area, one cephalocoele in the parietal area and one cephalocoele in the frontoethmoidal region and one anencephaly. Maximum number of cases of CNS anomaly were of neural tube defects $14 / 30$ (47\%). Microcephaly was found to be $13 / 30(43.3 \%)$. Neural tube defects were found to be more in primigravida and microcephaly in multigravida.

Conclusion: Recognition of aetiological factors permits implementation of preventive measures in the society to decrease the incidence of this dreadful condition. In all cases of microcephaly, associated anomalies of eyes or ears or facial dysmorphism were noticed.

KEY WORDS: Dandy Walker Malformations, Holo-prosencephaly, Lumbar Myelomeningocoele, Cncephalocoeles, Consanguinity.

Address for Correspondence: Dr. Sailaja. K, Assistant Professor, Department of Anatomy, Govt. Medical College, Calicut, India. E-Mail: sailajakrishnapadam@rediffmail.com

\begin{tabular}{|c|c|c|}
\hline \multicolumn{3}{|c|}{ Access this Article online } \\
\hline \multirow{2}{*}{$\begin{array}{l}\text { Quick Response code } \\
\text { DOI: } 10.16965 / \text { ijar.2017.189 }\end{array}$} & \multicolumn{2}{|c|}{$\begin{array}{l}\text { Web site: International Journal of Anatomy and Research } \\
\qquad \text { ISSN 2321-4287 } \\
\text { www.ijmhr.org/ijar.htm }\end{array}$} \\
\hline & $\begin{array}{l}\text { Received: } 18 \text { Mar } 2017 \\
\text { Peer Review: } 19 \text { Mar } 2017 \\
\text { Revised: None }\end{array}$ & $\begin{array}{l}\text { Accepted: } 25 \text { Apr } 2017 \\
\text { Published (O): } 31 \text { May } 2017 \\
\text { Published (P): } 31 \text { May } 2017\end{array}$ \\
\hline
\end{tabular}

\section{INTRODUCTION}

Malformations were known to exist from time immemorial. About 2500 BC gross malformations were recognized in ancient Egypt. In fourth century BC Aristotle recognized malformations. To begin with structural abnormalities which were readily visible were recognized as malformation. There are a lot of such characters in Indian mythology like Kabanthan who had his head low positioned and Ashtavakram with kypho-scoliosis [1]. In $18^{\text {th }}$ and $19^{\text {th }}$ century embryology developed as a science. Embryologic research flourished and causations of malformations were understood and they were given a scientific basis. In early $20^{\text {th }}$ century more explorations were done and the mechanism of malformations was more clearly understood.

Environmental causations of malformations particularly of central nervous system (CNS) were first described by Aschenheim in 1920 [2]. 
He published a child with microcephaly whose mother was exposed to radiation during pregnancy. Gregg- I discovered that rubella infection can cause serious malformation [3]. Lenz described chemical induction of malformation by thalidomide [4]. By the end of $19^{\text {th }}$ century $\mathrm{X}$-rays were discovered which started a new era in the research methodology of anatomy. We were able to identify the anomalies of internal organs with imaging techniques. By the mid $20^{\text {th }}$ century cross sectional imaging was produced which helped a lot in understanding and characterizing the lesions.

CNS malformations are one of the most common among congenital malformations rating to $5-10 \%$ of total malformations. Most of CNS malformations lead to death of foetus in utero or death in infancy or early childhood. They cause severe disability and patients have a short life span. Some of them are caused by gene mutations and some of them by environmental factors. But majority of malformations are of unknown aetiology. National Institute of Health of United States in 1975 a panel of experts from Bethesda Maryland, discussed and suggested the following definitions - "A malformation is a primary structural defect that results from an error in morphogenesis". Deformation is an alteration in shape and structure of a previously formed part [5].

There are several aetiological factors thought to be responsible for congenital anomalies of CNS. They include drugs, alcohol, viral infection, exposure to radiation, exposure to chemicals.

CNS develops from ectoderm. Knowledge of the development of brain is essential for understanding the congenital anomalies.

In this study anomalies resulting from disturbance of CNS development upto stage 3 were included. Disorders arising from stage IV, $V$ and $\mathrm{VI}$ are beyond the scope of this work, as those cases constitute part of cliniteria of neurophysicians. Therefore, the present study was performed to evaluate the congenital anomalies in the central nervous system.

\section{MATERIALS AND METHODS}

Patients of paediatric age group (1-12) years admitted to Pediatrics and Neurology wards during the period of 2002 April to 2003 April suspect to have congenital anomalies of CNS were followed up. Imaging studies were collected and tabulated. Other relevant investigations were collected to arrive at meaningful conclusions. Antenatally diagnosed cases of CNS anomalies were followed up. The anthopometric and aetiological parameters like gender, age, district, community, socio- economic status, consanguinity, family history of congenital anomalies, gravida, abortion, still birth, maternal diabetes, drug intake, maternal age, exposure to radiation, exposure to chemotherapy, febrile illness in $1^{\text {st }}$ trimester, obesity, maternal malnutrition, folic acid supplementation, zinc supplementation, psychological condition of mother and contraceptive failure was recorded.

Examination for associated anomalies of head, eyes, ears, nose, face, palate, thorax, abdomen and genitalia, back, upper limb, lower limb and additional points if any was also recorded. The Ultrasound, CT scan, MRI scan and other relevant investigations if any was also performed.

\section{RESULTS}

In the present study 30 cases of congenital malformations were identified. Out of 30 cases 14 of them were neural tube defects, 13 microcephaly, 2 Dandy Walker malformations and one holoprosencephaly (Fig-1).

Out of 14 neural tube defects 9 of them are lumbar myelomeningocoele, two encephalocoeles in the occipital area, one cephalocoele in the parietal area and one cephalocoele in the frontoethmoidal region and one anencephaly (Fig-2). Distribution among Hindus and Muslims was almost equal with a slight increase among Hindus. The Hindu patients were $53.33 \%$ and Muslim patients were $46.67 \%$ (Table 1 ). Only 3 belong to middle class. Rest of 27 are from low socioeconomic class. They are educationally and financially backward. They have low nutritional status (Table 2). 19 patients were males and 10 of them females. In one, sex was not determined because foetus was terminated at 26 weeks. The Male patients were $65.51 \%$ and female patients were $34.48 \%$ (Table 3 ).

The number of patients belongs to family history of nervous disorders, consanguinity,gravida, maternal age, abortion, drugs, 
febrile illness, folic acid supplementation, Zinc supplementation was shown in table-4. Fourteen patients showed abnormalities of eyes (Table5). Eleven patients showed abnormalities of ears. Eight patients had anomalies of both eyes and ears. Six of them are microcephalics and two of them with neural tube defects (Table-6). In the present study conducted, maximum number of cases of CNS anomaly were of neural tube defects $14 / 30$ (47\%). Microcephaly was found to be $13 / 30$ (43.3\%). Neural tube defects were found to be more in primigravida and microcephaly in multigravida (Table-7).

Fig. 1: Different types of congenital malformations identified in the study.

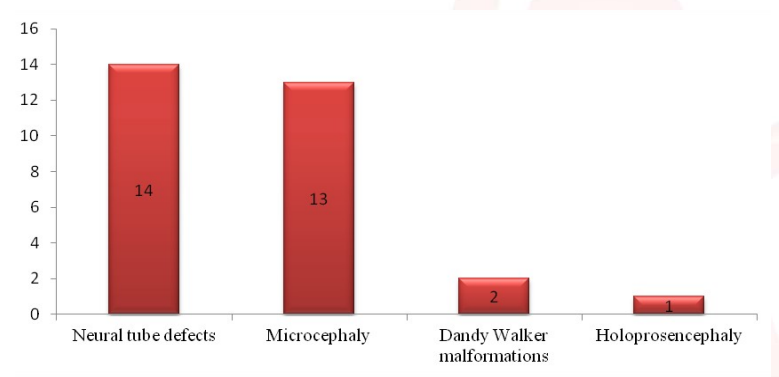

Fig. 2: Different types of neural tube anomalies identified in the study.

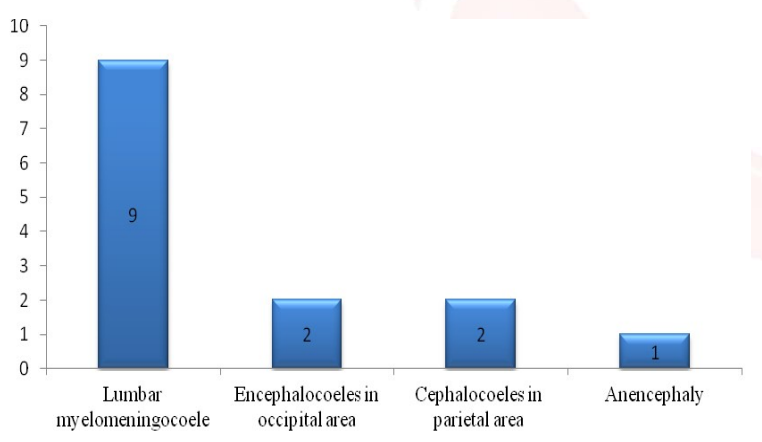

Table 1: Community wise distribution of patients in the study.

\begin{tabular}{|c|c|c|}
\hline Community & No. of cases & Percentage \\
\hline Hindus & 16 & 53.33 \\
\hline Muslims & 14 & 46.67 \\
\hline Total & 30 & 100 \\
\hline
\end{tabular}

Table 2: Socioeconomic status of patients in the study.

\begin{tabular}{|c|c|c|}
\hline Socioeconomic status & No. of cases & Percentage \\
\hline Middles class & 3 & 10 \\
\hline Low class & 27 & 90 \\
\hline Total & 30 & 100 \\
\hline
\end{tabular}

Table 3: Gender wise distribution of patients in the study.

\begin{tabular}{|c|c|c|}
\hline Sex & No. of cases & Percentage \\
\hline Males & 19 & 63.33 \\
\hline Females & 10 & 33.33 \\
\hline Sex not determined & 1 & 3.33 \\
\hline Total & 30 & 100 \\
\hline
\end{tabular}

Int J Anat Res 2017, 5(2.2):3819-23. ISSN 2321-4287
Table 4: Number of patients depending on various parameters.

\begin{tabular}{|c|c|}
\hline Parameters & Number \\
\hline Family history & 4 \\
\hline Consanguinity & 8 \\
\hline & 11- primigravida \\
Gravida & 12- Second gravida \\
& 7 - Multigravida \\
\hline & Mothers age between; \\
& 20 years -3 babies \\
Maternal age & $20-30$ years -11 babies \\
& $30-35$ years -5 babies \\
& 38 years---1 baby \\
\hline Abortion: & 4 \\
\hline Drugs & 02 mothers- antiepileptic drugs \\
& 02 mothers- antidiabetic drugs \\
\hline Febrile illness & 02 mothers in first trimester \\
\hline Folic acid & $\begin{array}{c}13 \text { mothers- ignorant about regular intake of folic } \\
\text { acid during pregnancy. }\end{array}$ \\
\hline supplementation & of zinc tablets. \\
\hline Zinc supplementation & $\begin{array}{c}\text { No mothers give a positive history of regular intake } \\
\text { of }\end{array}$ \\
\hline
\end{tabular}

Table 5: Number of patients belongs to associated anomalies with eyes.

\begin{tabular}{|c|c|c|}
\hline & No. of cases & Percentage \\
\hline Microcephalics & $\mathbf{2}$ & $\mathbf{6 6 . 7}$ \\
\hline Neural tube defects & $\mathbf{1}$ & $\mathbf{3 3 . 3}$ \\
\hline Bilateral proptosis & 8 & 50 \\
\hline Hypertelorism & 4 & 25 \\
\hline Optic atrophy & 1 & 6.25 \\
\hline Bilateral papilloedema & 1 & 6.25 \\
\hline Sunken eyes & 1 & 6.25 \\
\hline Diminished vision & 1 & 6.25 \\
\hline Total & 16 & 100 \\
\hline
\end{tabular}

Table 6: Number of patients belongs to associated anomalies with ears.

\begin{tabular}{|c|c|c|}
\hline & No. of cases & Percentage \\
\hline Large prominent ears & 7 & 63.63 \\
\hline Low set ears & 2 & 18.18 \\
\hline Malformed right pinna & 1 & 9.09 \\
\hline Diminished hearing & 1 & 9.09 \\
\hline Total & 11 & 100 \\
\hline
\end{tabular}

Table 7: Number of patients belongs to other associated anomalies.

\begin{tabular}{|c|c|c|}
\hline & No. of cases & Percentage \\
\hline Neural tube defects & 14 & 46.7 \\
\hline Microcephaly & 13 & 43.3 \\
\hline Dandy Walker malformations & 2 & 6.7 \\
\hline Holoprosencephaly & 1 & 3.3 \\
\hline Total & 30 & 100 \\
\hline
\end{tabular}

\section{DISCUSSION}

The aetiological factors which are having important roles are found to be intake of drugs like glibenclamide and sodium valproate, consanguinity, irregular intake of folic acid, low 
socio economic conditions and febrile illness during first trimester. Low socioeconomic condition denotes nutritional deficiency during pregnancy, when the cells are undergoing active proliferation in the embryo [6]. Recognition of aetiological factors permits implementation of preventive measures in the society to decrease the incidence of this dreadful condition. In all cases of microcephaly, associated anomalies of eyes or ears or facial dysmorphism were noticed. Ultrasound screening of pregnant ladies is a very useful and harmless method of investigation for the early diagnosis of anomalies, so that a foetus with a gross anomaly can be terminated. Early diagnosis also helps in intrauterine correction of anomalies like spina bifida.

Increased risk of neural tube defects among people in low socio economic group has offered a clue to the factors that poor families are different form affluent families. Poor nutrition is the obvious reason. Effect of poor nutrition is magnified in the developing embryo where active cell proliferation occurs [7]. Risk factor for microcephaly includes alcohol use, inadequate weight gain during pregnancy, inadequate prenatal care, black race and low education.

In this study 27 out of 30 patients belong to low socioeconomic class. They are educationally backward. Their nutritional status is poor. They cannot afford to take balanced diet with plenty of fruits and vegetables in their diet. Fruits and vegetables are good source of folic acid. They do not know the importance of prenatal care. Family studies show multiple affected siblings' in microcephaly. Consanguinity provides strong evidence for an autosomal recessive mode of inheritance in microcephaly (Penrose 1956, Koch 1959) $[8,9]$. It was also noted that abnormalities of the neural tube were common among siblings. $6.5 \%$ in anencephaly and $4.4 \%$ in spina bifida [10].

Though maternal age was found to be associated with various anomalies, there was no association of maternal age and congenital anomalies in the present study. Abortion is the way of nature to get rid of nonviable embryos. In this study 4 cases out of 30 (13.3\%) give history of previous abortions. Products of conception of 25 cases were analysed and no causes of malformations were detected and the incidence of malformations in offsprings of mothers taking anticonvulsants drugs was $6 \%$.

In the present study two epileptic mothers taking valproic acid and two diabetic mothers taking glibenclamide gave birth to offsprings with CNS malformation. Two epileptic mothers are having babies with neural tube defects. Out of two diabetic mothers, one gave birth to baby with encephalocoele and one to baby with microcephaly. Fever and hyperthermia in early pregnancy increased the risk of neural tube defects [11]. It was reported that the viruses interfere with production of neurons as well as their migration [12]. In the present study mothers of two babies gave history of febrile illness in the first trimester. One gave birth to baby with neural tube defect and one to baby with microcephaly.

The importance of folic acid supplementation in the prevention of neural tube defects is given in much literature. As a method of primary prevention of neural tube defect, daily intake of 400 micrograms of folic acid is advised to women of reproductive age group by Public Health Service in 1992. In other countries like Australia and Netherlands women are advised to take 400 micrograms of folic acid every day. Grain flour is fortified with folic acid and women are advised to take plenty of fruits and vegetables.

\section{CONCLUSION}

Aetiological factors having important roles are found to be intake of drugs like glibenclamide and sodium valproate, consanguinity, irregular intake of folic acid, low socio economic conditions and febrile illness during first trimester. Low socioeconomic condition denotes nutritional deficiency during pregnancy, when the cells are undergoing active proliferation in the embryo. Recognition of aetiological factors permits implementation of preventive measures in the society to decrease the incidence of this dreadful condition. In all cases of microcephaly, associated anomalies of eyes or ears or facial dysmorphism were noticed.

\section{Conflicts of Interests: None}




\section{REFERENCES}

[1]. Marin-Padilla M. Prenatal and early postnatal ontogenesis of human motor cortex Sequential development of cortical layers. Brain Res. (1970a) ;23:167-183.

[2]. Aschenheim, Yamazaki, and J.N. A review of literature on radiation dosage required to cause manifest central nervous system distrubances from inutero and postnatal exposure. Pediatrics 1966; 37:877-902.

[3]. Gregg I, Stevenson, A.C., ohnston, M.P. Stewart, Golding P R. Congenital malformation: a report of a study of a series of consecutive births in 24 centres. Bull Wld. Health Org. 1966;34:25-29.

[4]. Lenz, Melnic, M. and E.D. Shields. Allelic restoration. A biologic alternative to Multi

[5]. factorial threshold inheritance.Lancet. 1976b;176179.

[6]. Plummer, G. Anomalies occurring in children exposed in utero to the atomic bomb in Hiroshima Paediatrics. 1952;10:687-693.

[7]. Merz T. Radiation induced malformation in man. In: D. Bergsma and RN Schimke eds: Cytogenetic, Environment and Malformation Syndromes. Birth Defects: Org: Art. Ser Vol.XII, No.5. Newyork NY, Alan R. Liss, Inc 1976;19-22.

[8]. Poliokov, G.I. Some results of research onto the development of neuronal structure of cortical ends of analyzers in man. J Comp. Neurol 1961;117:197212.
[9]. Penrose H, Hall J.G. Embryopathy associated with oral anticoagulant therapy. In D. Bergsma and RN Schimke. Cytogenetic Environment and Malformation Syndromes. Birth Defects Orig. Art. Ser. Vol.XII No.5, New york NY, Alan R. Liss 1976:33037.

[10]. Koch, Jones HL. Aberrant Neuronal Migration in the foetal alcohol syndrome. in: D. Bergsma, ed. Morphogenesis and malformation of face and brain. Birth Art, Ser. 1975;11(7).

[11]. Richards, Singh, R.P and D.H. Carr. Anatomic findings in human abortions of known chromosome constitution. Obstet Gynaec 1967;29:806-818.

[12]. Renwick J.H. Hypothesis- Anencephaly and spina bifida are usually preventable by avoidance of a specific but unidentified substance present in certain potato tubers. Brit J. Prev. Soc. Med 1972;26:6788.

[13]. Rakic, P. Mode of cell migration to the superficial layers of foetal monkey neocortex. J Comp. Neurol 1972;145:61-84.
How to cite this article:
Sailaja. K. A STUDY ON CONGENITAL ANOMALIES OF CENTRAL NERVOUS SYSTEM. Int J Anat Res 2017;5(2.2):3819-3823. DOI: 10.16965/ijar.2017.189 